\title{
Research on the Development Strategy of Ningbo Transportation Port \& Shipping Industry
}

\author{
Ningyu Zhang \\ College of Transport \& Communications, Shanghai Maritime University, Shanghai, China \\ Email: zhangningyu1116@foxmail.com
}

How to cite this paper: Zhang, N.Y. (2019) Research on the Development Strategy of Ningbo Transportation Port \& Shipping Industry. Journal of Transportation Technologies, 9, 474-488.

https://doi.org/10.4236/jtts.2019.94030

Received: September 15, 2019

Accepted: October 7, 2019

Published: October 10, 2019

Copyright $\odot 2019$ by author(s) and Scientific Research Publishing Inc. This work is licensed under the Creative Commons Attribution International License (CC BY 4.0).

http://creativecommons.org/licenses/by/4.0/

\section{(c) (†) Open Access}

\begin{abstract}
Firstly, the development background of Ningbo Transportation Port \& Shipping Industry is analyzed on a spatial scale. Based on that, the strategic goal of Ningbo transportation port Port \& Shipping Industry is put forward, and strategic path analysis of strategic objectives is carried out. Finally, with the dynamic resource view, the strategic integration model of Ningbo Port \& Shipping Industry is proposed.
\end{abstract}

\section{Keywords}

Transportation, Port \& Shipping Development Strategy,

Dynamic Resource View, Integrated Model

\section{Introduction}

According to the 13th five-year port and shipping development plan of Ningbo city, Ningbo should build a modern hub port with "world-class modern hub port" and "one ring and three centers" as the main line, and build a modern hub port with sufficient infrastructure capacity, perfect multimodal transport system, and reasonable shipping structure and developed port and shipping culture construction. However, there are not sufficient researches on the development strategy and strategy of Ningbo transportation port and waterway. Zheng changjuan [1] analyzed the competitive position of Ningbo port and the development trend of port service industry; Wei youfang [2] proposed the concept of Ningbo port logistics mode development by analyzing the world's typical port logistics mode; Zhuang peijun et al. [3] put forward the strategic path of supply-side reform of Ningbo transportation system with the strategic focus of "reducing cost, increasing efficiency and improving quality". However, the above litera- 
tures are not detailed enough on the development strategy of Ningbo transportation and relevant strategies for the development of port and shipping industry. This paper analyzes the development conditions of Ningbo transportation port and shipping industry from the global scale, regional scale and local scale, and puts forward the corresponding development strategies for the port and shipping industry. Meanwhile, by referring to the theory of "dynamic capability" in strategic management, this paper puts forward the strategic integration model of Ningbo port and shipping based on the dynamic resource view, and gives some suggestions for Ningbo transportation strategy development to maintain the core competitive advantage.

\section{Analysis on Development Conditions of Ningbo Transportation Port and Waterway (Spatial Scale)}

1) Analysis of the development conditions of ports and navigation on a global scale

"One Belt and One Road" is the abbreviation of "silk road" economic belt and " 21 st century maritime silk road" [4]. Ningbo has been an important port on the maritime silk road since ancient times, with a glorious maritime history. As early as the Tang dynasty, the port of Ningbo (Mingzhou) was the prosperous port of the world; During the northern Song dynasty, Mingzhou port had close trade relations with Korea, Japan, southeast Asia and the Arab world; However, Ningbo missed the period of shipping development because of the sea ban policy in the early Ming dynasty; It was not until the Qing dynasty, after the opening of the coastal docks, that Shanghai rose rapidly, and a large amount of capital and talents in Ningbo were able to build in Shanghai. Back to modern times, at the end of 2005, "Ningbo-Zhoushan port" promoted the integration of ports, implemented the integration of port resources, and the port developed rapidly with amazing momentum. By the end of 2015, the cargo throughput of Zhoushan port in Ningbo reached 889 million tons in 2015, ranking first in the world port for seven consecutive years. Ningbo-Zhoushan port has established trade routes of ports in more than 100 countries and regions, with a total of 235 routes, radiating east Asia and the entire Pacific rim to the east. The glory of Ningbo maritime silk road deserves our expectation.

Zhoushan port of Ningbo has the conditions of being the main hub port of international coastal ports along the silk road: Zhoushan port in Ningbo is the largest comprehensive port in the world. The average water depth of natural channel is 30 - 100 meters. Iron ore, oil, coal and other bulk commodities transportation and crude oil transportation business is mature; It is also close to the main international shipping routes in the asia-pacific region, radiating to east Asia, asean and the Pacific rim.

Based on the analysis of the global scale strategy of Ningbo transportation port development, it is found that Zhoushan port of Ningbo has been built as a major hub port of the coastal ports along the silk road. At the same time, driven by the port economic circle effect, three centers have been developed together, 
namely, "manufacturing innovation center, economic and trade cooperation and exchange center, port and shipping logistics service center". This situation not only meets the needs of the overall national strategy, but also brings a new opportunity for Ningbo's outward development.

2) Analysis of the development condition of port and navigation at regional scale

From the regional scale analysis, Ningbo has obvious regional advantages. Ningbo is located in the $t$-shaped intersection of the Yangtze river economic belt and the national north-south coastal traffic channel. And Ningbo's distribution network is developed and convenient. The expressway entering the port is closely connected with the national expressway network, and 506 kilometers of deep-water shoreline is planned for the port. The deep-water length of a super-large berth of 300,000 tons or more is about 20 kilometers [5], and the conventional channel is nearly 5000 kilometers. The highest artificial channel can carry 300,000 tons of ships. At present, key waterway projects, such as container transport channels dominated by three-level waterways, are being built to form the backbone channel layout framework of "north network and south route, with 20,180-kilometer waterways". The total length of inland waterways is 9762 kilometers, ranking fifth in China.

Ningbo Zhoushan port is vigorously developing the sea-railway combined transport business, increasing the sea-railway combined transport logistics business, expanding the hinterland of Ningbo Zhoushan port and serving the export-oriented economic development of the central and western regions. Ningbo Zhoushan port container sea-rail combined transport business started at the beginning of 2009, and has successively developed the business in Taizhou, Wenzhou, Quzhou, Yiwu, Jinhua, Shaoxing and other places in the province. Relatively far provinces have developed Nanchang, Shangrao, Yingtan, Xinyu, Jingdezhen, Xiangyang, Lanzhou, Xinjiang, Hefei and other places of sea canal railway transport business. In 2015, the total volume of combined transport between rivers and oceans exceeded 200 million tons. Twenty cities have opened sea-rail connections, and it makes the Sea-rail transport volume reached 170,000 teu.

The above distribution network makes Ningbo develop into the Yangtze river economic belt of the river and sea combined transport center has good congenital conditions.

At the same time, from the perspective of regional high-end shipping services, Ningbo shipping center is well built and Ningbo shipping exchange enjoys a good momentum of development. As a platform for strengthening the province, Ningbo shipping exchange provides "one-stop" services including shipping trading, shipping finance, shipping economy, information consulting, policy research and policy. In particular, the maritime silk road trade index developed by Ningbo shipping exchange was officially released, which is one of the achievements of "One Belt and One Road" international peak BBS. Therefore, it can be seen that Ningbo shipping office has a good development prospect and has the 
strength to become provincial shipping exchange in Zhejiang.

\section{3) Analysis of port and navigation development conditions at local scale}

The strategic conception of the local scale distribution system mainly enables the port to connect with various transportation modes effectively, which makes Ningbo also possesses good development conditions.

In 2018, the accumulative trade volume of import and export at Ningbo port reached USD 242.79 billion, with a year-on-year growth of $18.9 \%, 6.3 \%$ higher than the average growing rate of import and export industry in China. Among which, the export trade volume was USD 167.57 billion, with a year-on-year growth of $14.9 \%$; the import trade volume was USD 75.23 billion, with a year-on-year growth 29.2\%; and the trade surplus was USD 92.34 billion, increased by $5.3 \%$ on year-on-year basis.

The present situation of Ningbo city's distribution system is analyzed from the following aspects: At present, Ningbo city has many kinds and large scale of port transportation; The main skeleton outline of the external distribution channel of Ningbo port is under construction; The inner system of Ningbo beilun port distribution network has been basically formed, and the construction of supporting facilities has been effective; Positive progress was made in expanding customs clearance at ports.

Local scale involves other port shipping logistics platform and emerging platform. Firstly, from the perspective of the analysis platform for electronic port, Ningbo's single window for international trade (Ningbo e-port) is currently the standard port clearance platform of Ningbo, and it is committed to the new mode of whole-process clearance. At present, the platform can handle a series of businesses such as enterprise qualification certificate, certificate of origin, transportation means, manifest declaration, goods declaration, processing trade, tax treatment, cross-border e-commerce, goods customs clearance, export tax refund and public inquiry. Meanwhile, it is worth noting that the electronic port already has the vehicle AIS system and ship GPS real-time system, as shown in Figure 1. And it will be helpful for the development of "car-free carrier" platform and other local port and shipping logistics platforms in the future. The flow chart of Ningbo electronic port import and export customs clearance (Figure 2) clearly shows the number of transaction Numbers of Ningbo's trade with other countries, which is of certain significance for guiding enterprises' foreign trade logistics business. Logistics platform is not a single business platform, it is a new business model based on ecology, with long-term strategic value. Thus, the strategic conception of scientific development and research of port and shipping logistics platform is also worth in-depth discussion and analysis.

\section{Analysis of Strategic Target of Ningbo Transportation Port and Navigation Industry Development}

Strategic objectives of Ningbo transportation port and shipping can be described as follows: Ningbo-Zhoushan will be built as the main international hub port of the silk road, which will drive the development of the Yangtze river economic 


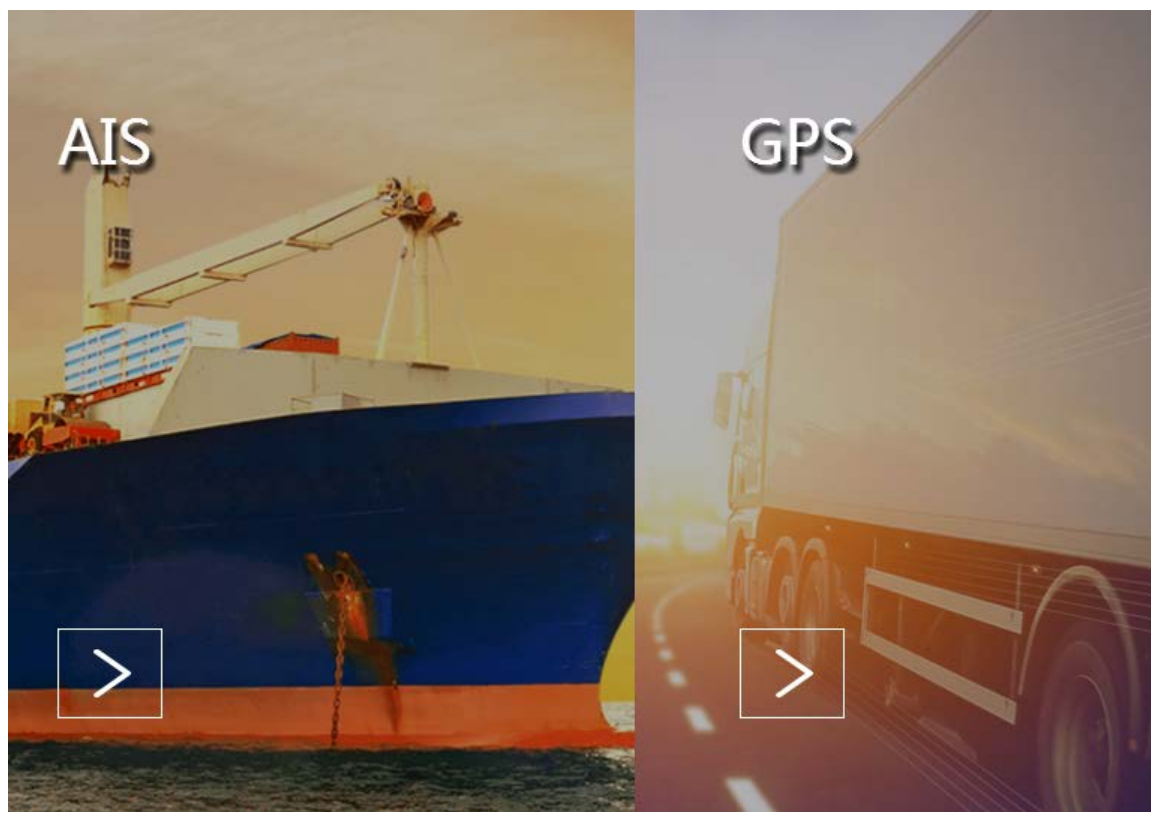

Figure 1. AIS system of Ningbo electronic port.

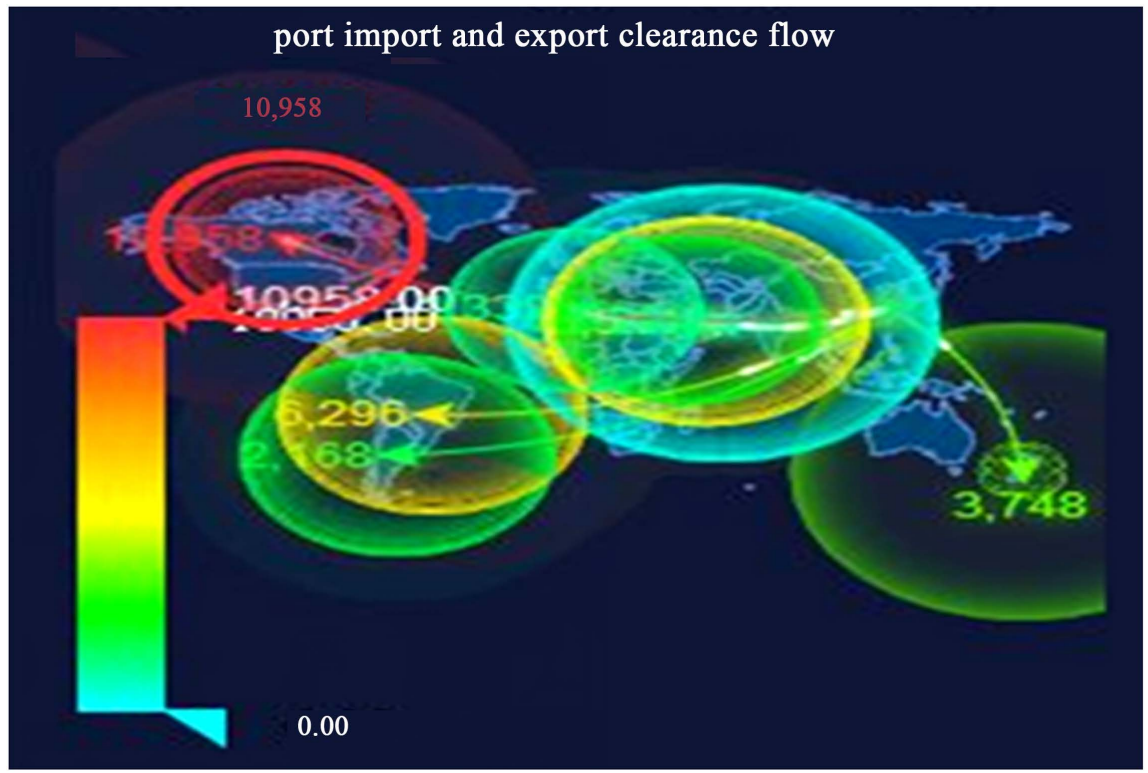

Figure 2. Flow chart of Ningbo electronic port import and export customs clearance.

belt with the effect of port economic circle. Then, through a series of measures, including developing Ningbo shipping exchange to become a powerful provincial construction strategic platform for ports and shipping in Zhejiang, it can improve and optimize the structure of port logistics supporting services and distribution system, upgrade and reform the new information service platform of various types of ports and navigation, promote the development of the new port and navigation platform mode, build a comprehensive transportation system with the global first-class modern hub port as the focus, and eventually build Ningbo into a world-class intelligent international port city. 


\section{1) Ningbo-Zhoushan port "silk road" international hub port strategy}

Ningbo-Zhoushan port will be vigorously built as the main international hub port of the silk road. The maritime silk road is a time-honored maritime economic and trade road as well as a major channel for the development of international and regional trade. This is a historic international strategic opportunity with far-reaching implications. We will restart the strategy of "maritime silk road", build the Ningbo-Zhoushan port as the main international hub port of the silk road, and realize cooperation with ports in southeast Asia, mainland India and Sri Lanka. We will launch "the 21st century maritime silk road" port alliance, develop regional transnational cooperation, and expand the number of international and regional cargo flights along the silk road. Aiming at the internal environment, we can improve the e-port supporting service platform business and build an interconnected land and sea distribution network. Then the sea-rail combined transport business has become more mature. The development of "three centers" is driven by the effect of port economic circle, and the port radiates the economic and trade development in the hinterland, which is of great significance to the planning strategy of Ningbo-Zhoushan port in the future. It also lays a foundation for Ningbo-Zhoushan port to build a "free port".

2) "The Yangtze river economic belt of the river and sea combined transport center" strategy

From the long-term development of the region, Ningbo strive to be the Yangtze river economic belt sea rail transport center has great strategic value. At present, the annual turnover of goods in the Yangtze river accounts for more than 30 percent of the total goods in the basin, and the dependence of goods on water transportation is increasing consantly. Due to the obvious trend of constructing industrial zone along the river in the pan-yangtze river delta area, the support of river-sea combined transport service is urgently needed. And this strategy has also brought a huge demand for river and sea transportation to Ningbo-Zhoushan port. Seizing the great opportunity, Zhoushan jianghai combined transport service center was established, and a series of dock projects were established and advanced. It comprehensively improves loading and unloading, storage and other basic facilities, and at the same time optimizes and improves the trunk and branch, builds public information platform, realizes the shipping the real-time exchange of information, and strives to build "Yangtze river economic belt of river and sea multimodal transport center".

3) The Ningbo shipping exchange strategic platform construction in Zhejiang province into a powerful province in port and waterway administration construction

We need to improve the credibility of Ningbo shipping exchange and its "haisi index" market influence. Under the general trend of integrated port information platform in Zhejiang, reasonable planning of Zhoushan shipping exchange makes it naturally integrate into the construction of integrated port and navigation information service in the whole province. Meanwhile, Zhoushan shipping exchange is in urgent need of developing shipping derivatives trading products, 
such as "freight index of combined transportation between river and sea" and other products. We should open up more shipping financial payment service functions, sign a strategic cooperation agreement with the shipping ports association (similar to China shipowners mutual insurance association), and expand the scope of business operation of the institutions, so as to strengthen the credibility of the shipping exchange.

4) Optimization of distribution system and integration strategy of port resources

The construction of internal channel is mainly to build a container distribution channel based on three-level channels, and to build distribution facilities for bulk cargo. At the same time, it is necessary to increase the construction of collection and distribution roads, and plan to build railway container operation stations and deditated container freight yard stations. We need to build "inland anhydrous harbor", improve the convenience of multimodal transport service, and integrate the high-quality resources of zhejiang port, so as to improve the core competitiveness of Zhoushan Zhoushan port. It will make ningbo-Zhoushan port an important link between the "maritime silk road" and the "golden waterway of the Yangtze river".

\section{5) Information platform integration trend}

We should clarify the positioning and functions of various port and navigation information platforms, and not build too many information platforms repeatedly.With the general trend of information platform integration in Zhejiang province, this paper analyzes the cooperation and integration of various platforms, and studies the profit distribution of various platform businesses under the integration of port and shipping platforms by combining the benefit distribution theory of game theory. It also puts forward Suggestions to promote the construction and innovative development of new port and shipping information platform, such as upgrading the business construction of Zhoushan river combined transport service platform, promoting the function business of Zhoushan electronic port platform, and providing big data of the function of electronic port platform to help port and shipping enterprises develop. At the same time, it is indispensable to demonstrate and develop such platforms as shipping blockchain insurance platform, car-free carrier platform, 4PL fourth party information platform and Zhoushan international cruise platform.

\section{Strategic Research and Analysis of Zhoushan Transportation Port and Navigation Development}

1) Take the location advantage as the competitive capital to reproduce the glory of the silk road

In order to become the main international hub port of "maritime silk road", ningbo-Zhoushan port needs to make full use of high-quality port resources, take the lead in seeking extensive exchanges and cooperation with Hong Kong, Macao, Taiwan and Asean regional economic and trade projects, expand to larger cooperation areas gradually, and improve the status and influence of silk 
road construction constantly [6]. We will speed up shipping services between Zhoushan port and ports of other countries and regions, and increase the number of ocean trunk lines, offshore feeder lines and domestic trade lines. In addition, we should cooperate with scientific research institutions to demonstrate and analyze the feasibility of opening more affiliated routes by applying the optimization theory of operation planning, study the feasibility of berth upgrading and improving the cargo turnover rate, and analyze the construction scheme and return on investment of automatic pilot vehicles at container automatic terminals. Subsequently, efforts can be focused on the establishment of Zhoushan-Zhoushan port free trade zone and complete the strategic planning of the construction of "the free port". It can not only focus on oil storage and transfer business, increase oil resource allocation capacity, but also give play to the effect of port economic circle, promote the liberalization of oil commodity trade, and develop offshore trade and offshore financial business.

2) The construction of "Yangtze river economic belt of river and sea combined transport center" to demonstrate the linkage between river and sea

With the advantages of iron ore transfer base and liquid chemical storage and transportation base in Zhoushan, we can complete the whole river and sea transportation with the same ship. And Ningbo should be built into a hub of river-sea combined transport [7], so as to improve the layout of river-sea combined transport ports and wharves, coordinate with the policies of the Yangtze river economic belt and the construction of wharves along the Yangtze river's golden waterway, drive the linkage development between ports and the hinterland along the river, and carry out strategic cooperation agreements with other inland ports. What's more, blockchain technology is also a hotspot in future research. The possible direction of the application of blockchain in the water transport industry lies in the field of inland water transport. In particular, the fragmentation of the market and the mutual harm between upstream and downstream enterprises can be solved by blockchain technology. Relatively speaking, the inland river market has no reaction of large enterprises to the change of the established interest pattern, and is relatively controllable [8]. Thus, for Zhoushan to establish the "Yangtze river economic belt, river and sea combined transport center" strategic planning, the reasonable establishment of inland water transport block chain platform is undoubtedly a icing on the cake.

3) Ningbo shipping exchange will be built to improve the influence of the haisi index

It is suggested that Zhoushan shipping exchange not be included in the reorganization plan of Zhoushan Zhoushan port, and the shipping exchange be assessed according to the public welfare nature [9]. After strengthening the strategic cooperation between Zhoushan shipping exchange and the world maritime organization, the shipping exchange will face long-term challenges and opportunities from TPP, TTIP, RCEP, FTAAP and other international trans-regional cooperation agreements in the future. Hence the shipping exchange must make 
strategic arrangements. Improving the influence of "One Belt and One Road" maritime silk road index released by shipping exchange, developing shipping financial derivatives trading business and similar product development of "river transport freight index" are also important measures to attract talents of port and aviation informatization to build and develop aviation exchange platform.

4) Optimize the distribution system and integrate port resources

Reasonable development and allocation of port shoreline resource allocation can realize sustainable development [10], balance flights in the port area, optimize resource allocation of container yard construction outside the port, and improve the efficiency of goods in and out. We should plan the construction of railway container operation station and special container freight yard station, and develop the sea-rail combined transport business of Zhoushan port of Zhoushan scientifically. External land connection channels can choose to optimize the expressway and national highway 329 in beilun district, increase the external traffic channels of daxie island, and build the high-grade highway of jishuang. It can fully dredge the land-land railway and inland-river water transportation channel, strengthen the construction of anchorage channel, optimize the environment of Zhoushan port, vigorously build inland waterless port, and promote the diversified development of port collection and transportation mode.

For the integration of port resources, we must remove the estrangement between the two ports administratively [11]. Because the integration of port resources requires the unified operation and management of various cooperative ports, we should avoid independent administration, and further integrate competition and cooperation. Competition for supply, hinterland and shipping resources virtually increases internal consumption, and vicious competition inevitably brings low efficiency of external network allocation [12]. Therefore, we should avoid the homogenization construction, optimize the internal supply chain, strengthen the coordinated development of ports and shipping, establish an information sharing platform, and form strategic alliances with ports along the route to improve the competitiveness of ports.

5) Integrated logistics platform, moderate development and innovation platform

On the one hand, we should improve the information level of ports and shipping platforms. If we want to realize the integration of the province's large customs clearance platform, we must do a good job in the coordinated development of logistics resources [13]; otherwise, for example, the supply and demand platform construction of Zhoushan logistics association is currently in an abandoned state. On the other hand, we should expand and upgrade the original electronic information platform, and improve the integration of logistics resources. For instance, the function of Zhoushan electronic port supports the declaration of highway and railway manifest, but the construction investment of cross-border e-commerce platform should also be cautious. And "transport to where" logistics platform development model is very useful for reference. Final- 
ly, we must vigorously support Zhoushan hot innovation port and navigation information platform construction. Ernst \& young professional company with block chain Guard time cooperation to create the first shipping insurance block chain platform [14], the block chain platform to receive information and the impact on pricing or business process information to make rapid response. Ningbo donghai insurance group Co., Ltd., in collaboration with "China shipowners mutual insurance association" institutions, conducted similar demonstration that blockchain insurance platform business can be developed, so they can try to seize the blockchain insurance platform market."Fourth party" logistics platform can make use of its powerful resource integration ability and management consulting skills to recommend the most suitable third-party logistics suppliers and technical suppliers [15] for customers, and provide unique supply chain solutions. Morever, Ningbo-Zhoushan port can develop the fourth party information platform of "dry bulk shipping"; Car-free carrier refers to an operator who does not own a transport vehicle and does not assume the responsibilities and obligations of the carrier, but signs a contract of carriage of goods with the shipper as a carrier and completes the carriage of goods by road [16]. At present, "car-free carrier companies" in Zhoushan include Zhoushan port international logistics, Zhoushan wanlian, etc. [17]. However, such enterprises transform from traditional businesses, and their thinking openness is not high enough. However, for the government, it can still increase investment and financing to build an information service platform of "car-free carrier" and build a perfect credit evaluation system.

\section{Ningbo Port and Shipping Strategy Integration Model Based on Dynamic Resource View}

\section{1) Strategic planning of dynamic resource view}

"Dynamic capability" is the theory of enterprise strategic management. "Dynamic capability theory" analyzes the resource situation of an organization [18]. Dynamic capability emphasizes the integration, combination, acquisition and adaptation of resources and capabilities, and emphasizes the promotion of pioneering learning to achieve sustainable advantages. And pioneering learning capacity is a way to focus on change in order to provide new strategic ideas for the organization in the long run. External learning of technological knowledge emphasizes the ability to change direction. However, the dynamic capability theory emphasizes the short-term competitive advantage and relies too much on external scientific and technological innovation, which has some contradictions with the core goal of "world-class modern hub port" developed in Zhoushan port and shipping strategy.

The concept of dynamic resources originates from the theory of dynamic capability in strategic management. Compared with "dynamic capability", "dynamic resource view" pays more attention to the updating mechanism and management strategy of the organization's resource capability system based on environmental change. Its preference for strategic selection is generally "al- 
liance" and "integration", which also coincide with the alliance and restructuring phenomenon of shipping industry in recent years.

The "dynamic resource view" is elaborated as follows: Dynamic analysis of internal and external environment, constantly reexamine in the process of strategy formulation and implementation of the external environment and the change of the organization itself and the effect of the implementation of the strategy of organization. It adjusts and enhances the functions and resources of the organization through dynamic functions to match the internal structure of the organization with the changing environment. And with the change of internal and external conditions of the organization, it predicts the combination of innovative factors and new strategic resources in the future, and makes necessary and timely adjustments to the organizational strategy system, so that the organization can better meet the changes of the environment and optimize the strategy. In this way, it can better develop and participate in the competition more effectively and obtain sustainable competitive advantages [19]. As for Ningbo's strategy of developing international port hub port city, this chapter, based on "dynamic resource view", guides Zhoushan port and shipping industry to seize opportunities and seek sustainable development in the dynamic environment.

The strategic planning steps of "dynamic resource view" are as follows:

Step 1 Examine external port and shipping development environment. First of all, we judge the external environment of Zhoushan port and waterway industry development is the role of "incentive" or "stagnation", and from a global scale, regional scale and city scale, the above three aspects to understand Zhoushan if there is a chance or is in the center of something or some network node location. Once it can become the central node of a certain network space, it will certainly bring the improvement of city status and rank sequence for Ningbo.

Step 2 Assess internal resources and capabilities. According to the evaluation index of Zhoushan port city, we should analyze the achievements in various stages at present and accurately determine the city positioning of Ningbo. Draw up the city competition strategy suitable for Ningbo's development, and then seize its own development advantages to make up for its own shortcomings. Eventually, according to the experience of the benchmark cities, reasonable strategic measures should be taken to make up the resource gap, and scientific planning and distribution of internal resource allocation should be carried out.

Step 3 Judge the future scenarios. We forecast the development of each port and navigation index under different development conditions, and analyze the possibility of upgrading the city level under each development situation.

Step 4 Develop port and shipping performance index system, system construction and dynamic feedback. By linking the relevant elements of each competitive strategy with the relevant indicators, so that each indicator can correspond to the key elements of the strategy, we can timely adjust the industrial structure.

2) Ningbo port and shipping strategy integration model based on dynamic resource view 
Evaluation data are extracted from the evaluation index system of Zhoushan city internationalization construction issued by the general office of Zhoushan municipal people's government in 2016. The evaluation index system of Ningbo's internationalization construction is divided into three levels: first-level index, second-level index and third-level index. Related to port and shipping in the document is the first-level index of "port internationalization". There are also three secondary indicators in the document, including sea (river) port development, international function and airport development, which reflect the development level of international port cities [20]. In view of the focus of this paper is on the direction of port and navigation, it focuses on the analysis and statistics of the direction data of port and navigation, and the specific evaluation index system is shown in Table 1.

The strategic integration model of port and navigation should fully consider the factors of environment and internal resource capacity. Meanwhile, the model needs the ability to interpret the changes in time and space, which shows that the strategy can adapt to the changing environment. At the same time, the model needs the adjustment of resource allocation mode with internal connections and its discontinuous process, timely transformation of strategy and generation of new strategy $S 1$ suitable for the new environment.

According to the strategic connotation of "dynamic resource view" and the evaluation index system table of Zhoushan city internationalization construction, a strategic integration model of Zhoushan port and navigation based on dynamic resource view is proposed. The framework emphasizes the dynamic

Table 1. Zhoushan city internationalization construction evaluation index system table (port and shipping).

\begin{tabular}{|c|c|c|c|c|c|c|}
\hline First-level index & $\begin{array}{l}\text { Second-level } \\
\text { index }\end{array}$ & Third-level index & Unit & $\begin{array}{c}\text { Current } \\
\text { value (2015) }\end{array}$ & $\begin{array}{l}\text { 13th five-year } \\
\text { target (2020) }\end{array}$ & Directive organization \\
\hline \multirow{7}{*}{$\begin{array}{c}\text { Port } \\
\text { internationalization }\end{array}$} & \multirow[t]{2}{*}{$\begin{array}{l}\text { Port } \\
\text { development } \\
\text { situation }\end{array}$} & Container throughput & TEU & 1982 & $>2000$ & $\begin{array}{l}\text { Municipal transportation } \\
\text { committee }\end{array}$ \\
\hline & & Port throughput & $100 \mathrm{Mt}$ & 5.1 & 5.8 & $\begin{array}{l}\text { Municipal transportation } \\
\text { committee }\end{array}$ \\
\hline & \multirow{3}{*}{$\begin{array}{l}\text { International } \\
\text { ports business } \\
\text { situation }\end{array}$} & $\begin{array}{c}\text { Number of international } \\
\text { liner routes }\end{array}$ & Piece & 183 & $>190$ & $\begin{array}{c}\text { Municipal transportation } \\
\text { committee }\end{array}$ \\
\hline & & $\begin{array}{c}\text { Number of international } \\
\text { port organizations established }\end{array}$ & $\mathrm{n}$ & 0 & 1 & $\begin{array}{l}\text { Municipal transportation } \\
\text { committee }\end{array}$ \\
\hline & & $\begin{array}{c}\text { International shipping } \\
\text { index number }\end{array}$ & $\mathrm{n}$ & 2 & $\geq 3$ & $\begin{array}{c}\text { City port anti-smuggling } \\
\text { office }\end{array}$ \\
\hline & $\begin{array}{l}\text { International } \\
\text { cooperation } \\
\text { in running }\end{array}$ & $\begin{array}{l}\text { The number of international } \\
\text { ports and shipping logistics } \\
\text { well-known schools }\end{array}$ & $\mathrm{n}$ & 3 & * & $\begin{array}{c}\text { Municipal Education } \\
\text { Bureau }\end{array}$ \\
\hline & $\begin{array}{l}\text { schools and } \\
\text { harbor culture }\end{array}$ & $\begin{array}{l}\text { Number of headquarters and } \\
\text { regional representative offices } \\
\text { of international organizations }\end{array}$ & $\mathrm{n}$ & 1 & 5 & City business committee \\
\hline
\end{tabular}


and adaptability of strategy to external environment and internal resources, and analyzes the uncertainty and unpredictability of environmental change, so as to increase the dynamic resilience of strategy. In the dynamic environment, the logical concept of integration of internal and external resources and strategies of Zhoushan port and navigation have a mutual effect. And through the comparison with Zhoushan city internationalization construction evaluation index system, we can analyze the strategic process evaluation and strategic process results. Consistency in strategy design and implementation is achieved in practice, as shown in the model framework in Figure 3.

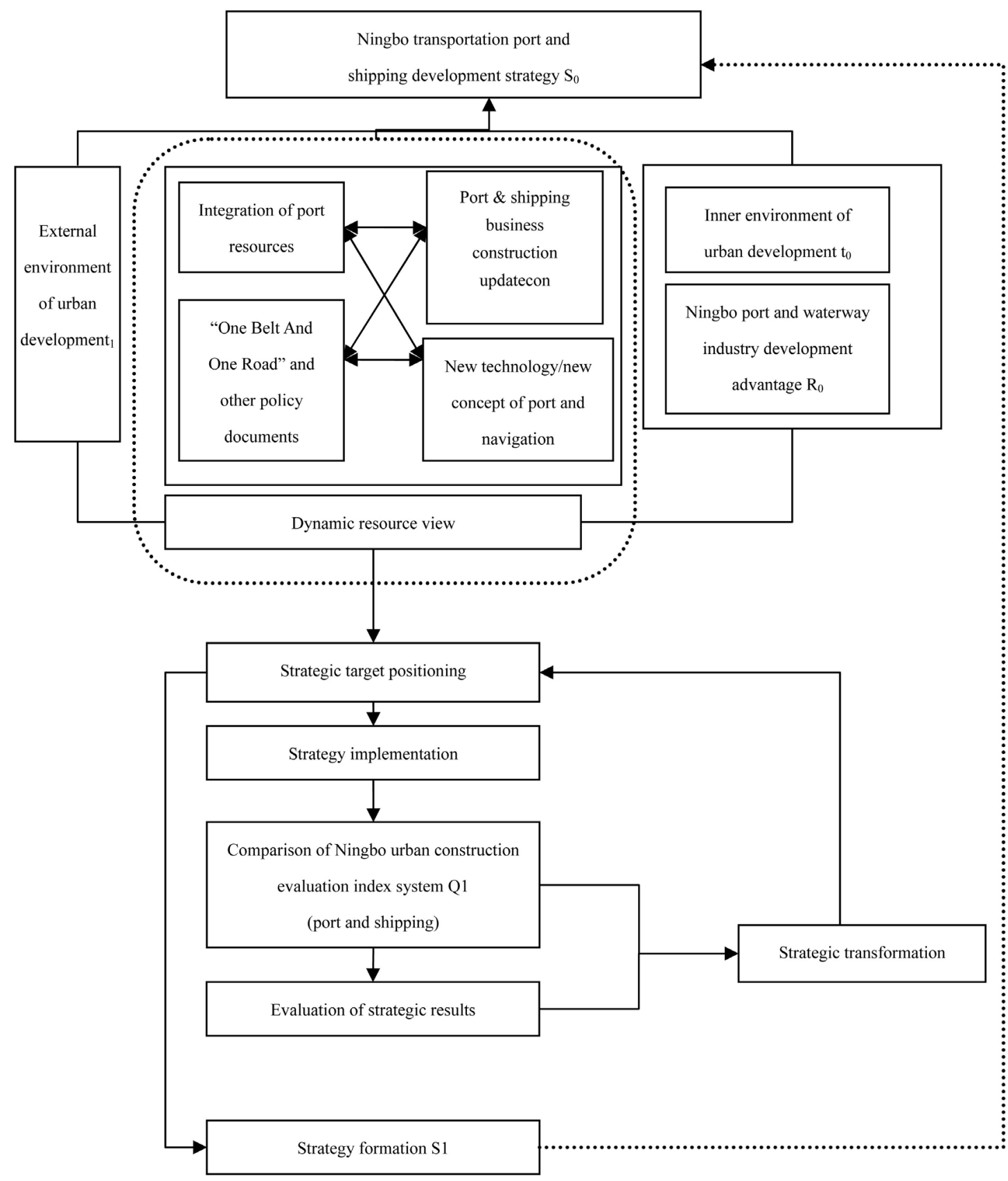

Figure 3. Strategic integration model of Zhoushan port and shipping based on dynamic resource view. 


\section{Conclusion}

This paper analyzes the strategic target of Zhoushan transportation port and navigation industry development, and evaluates the strategy of subdivision of the strategic target. Combining with the theory of "dynamic capability" of strategic management, this paper puts forward the "dynamic resource view" under the background of port and shipping, and obtains the strategic integration model framework of Zhoushan port and shipping industry. This model emphasizes the "dynamic adaptability" of the strategy to the external development environment and internal core resources, and guides us to evaluate the implementation results of the strategy against the Zhoushan urban construction system and moderately adjust the strategy to maintain the core competitiveness of the development of Zhoushan port and shipping industry.

\section{Acknowledgements}

I would like to express my gratitude to my professor Zhao, from whose lectures I benefited greatly. Finally, I wish to extend my thanks to the department manager of Ningbo shipping exchange who supplied me with materials of great value.

\section{Conflicts of Interest}

The author declares no conflicts of interest regarding the publication of this paper.

\section{References}

[1] Zheng, C.J., Zou, D.L. and Gu, Y.J. (2014) Research on the Development Strategy of Port-Adjacent Service Industry Based on Port Intergenerational Evolution-A Case Study of Ningbo Port. Science and Technology Management Research, 34, 53-57.

[2] Wei, Y.F. (2010) Development Strategy and Mode of Ningbo Port Logistics. Zhejiang University of Technology, Hangzhou.

[3] Zhuang, P.J., Zeng, Q., Ye, C.H. and Lin, Y. (2018) Spatial Scale and Path of Supply-Side Reform Strategy of Ningbo Transportation. Ningbo Economy, No. 7, $7-10+38$

[4] Xi, Z.X. (2013) One Belt and One Road (National Top-Level Cooperation Initiative). People's Daily.

[5] Mao, J.H. (2015) The Official Website of Ningbo-Zhoushan Port Group Is Sorted Out.

[6] Hu, G.F. and Liu, Li. (2014) Strategic Idea of "21st Century Maritime Silk Road" Trade Hub Port in Zhoushan, Zhejiang. Journal of Zhejiang Ocean University (Humanities and Sciences Edition), 31, 16-21.

[7] Wu, Y. (2010) Research on Optimization of Distribution System Serving Ningbo Port Logistics Development. Shandong University, Qingdao.

[8] Xie, X. (2018) How Much the Block Chain Will Influence the Water Transport Industry. China Shipping Inspection, No. 3, 47-49.

[9] Cheng, H.F. (2017) Several Suggestions on Promoting the "Maritime Silk Road" Index and Upgrading Development of Ningbo Air Exchange. Decision Consulta- 
tion, No. 5, 7-8+11.

[10] Chen, Y. (2017) Research on the Development of Zhoushan Port Distribution System. Zhejiang Ocean University, Zhoushan.

[11] Li, J.L. (2015) Problems to Be Paid Attention to in the Resource Integration of Zhejiang Coastal Ports. Port Economy, No. 10, 10-11.

[12] Hu, J. (2018) Port Efficiency Ascension Path Research-Ningbo-Zhoushan Port, for Example. China Business Theory, No. 7, 17-18.

[13] Xu, R.H. and Shi, A.F. (2018) On the Development Strategy of Port Logistics in Zhoushan Port of Ningbo. Ningbo Economy, No. 5, 29-31.

[14] Chen, T.T. (2017) The World's First Shipping Insurance Block Chain Platform Went Online. Pearl River Transport, No. 17, 42.

[15] Zhang, D.Y. (2013) Research on the Fourth Party Logistics Information Platform of Dry Bulk Shipping Industry. Wuhan University of Technology, Wuhan.

[16] Li, Y.L. (2018) Internet of Things Digital Supply Chain-New Format of Vehicle Free Carrier. China Logistics and Procurement, No. 14, 58-59.

[17] Xiao, L.B. and Chen, L. (2008) Research on the Application of Vehicle Free Carrier Operation Mode in Ningbo. Logistics Engineering and Management, 40, 43-44..

[18] Krzakiewicz, K. and Cyfert, S. (2017) Potential for Imitation as a Dynamic Capability of Organisation. Management, 22, 1-10. https://doi.org/10.2478/manment-2018-0001

[19] No. 165 of Yongzhengban (2016) Notice of General Office of Ningbo Municipal People's Government on Issuance of Evaluation Index System of Ningbo City Internationalization Construction.

[20] Yu, H.X. (2007) Research on Dynamic Resource Integration Model Construction and Flexible Strategic Management. Tianjin University, Tianjin. 